Н. О. Мельничук

\title{
СПІВВІДНОШЕННЯ ЕМОТИВНОСТІ ТА ОЦІННОСТІ У СТРУКТУРІ АНГЛІЙСЬКОГО ПРИКМЕТНИКА
}

Мельничук Н. О. Співвідношення емотивності та оцінності у структурі англійського прикметника.

Емотивність та оцінність $€$ важливими характеристиками англійських емотивних прикметників, що вживаються для кодифікованого вираження емоцій в мовленнєвому спілкуванні, справляючи емоційний ефект на реципієнта.

Ключові слова: емоція, емотивність, оцінність, семантична структура.

Мельничук Н. А. Соотношение эмотивности и оценочности в структуре английского прилагательного.

Эмотивность и оценочность являются важными характеристиками английских емотивних прилагательных, которые употребляются для кодифицируемого выражения эмоций в речевом общении, производя эмоциональный эффект на реципиента.

Ключевые слова: эмоция, эмотивность, оценочность, семантическая структура.

Melnychuk N. O. The Correlation of Emotiveness and Evaluation in the Structure of English Adjective.

Emotiveness and evaluation are important characteristics of English emotive adjectives. They are used for a codified expression of emotions in communication, producing an emotional effect on a recipient.

Key words: emotion, emotiveness, evaluation, semantic structure.

Сучасні мовознавчі дослідження останніх років поєднують у собі когнітивну, соціологічну та культурологічну спрямованість та висувають на передній план індивідуальні характеристики мовця як важливу складову вивчення центральної лінгвістичної проблеми - людина в мові. 
Дослідження різних галузей мовознавства свідчить про те, що жодна 3 них сьогодні не може існувати без дослідження емотивних аспектів мовних, мовленнєвих і текстових одиниць, адже емоційний аспект людської особистості відіграє неабияку роль у сучасній лінгвістичній парадигмі. Узаємозв'язок сфер раціонального й емоційного у свідомості та мисленні допомагає людині емоційно переживати те, що відображає мова, а тому роль емоцій у розвитку суспільства стала предметом неодноразового розгляду відомих лінгвістів.

Лексична семантика, вивченням якої присвячені праці відомих лінгвістів [3; 4; 7] відіграє неабияке значення при вивченні змістовного аспекту мови, адже саме завдяки застосуванню системного підходу при вивченні семантичних явищ результати наукових розвідок набувають особливої цінності й актуальності. Стаття присвячена дослідженню проблеми співвідношення емотивності й оцінності у структурі англійського прикметника. Актуальність обраної тематики зумовлена антропоцентричною спрямованістю сучасної лінгвістики та необхідності дослідження категорій емотивності та оцінності у структурі емотивних прикметників, що дає змогу виокремити основні характеристики емотивних елементів і дослідити особливості їх уживання в англійській мові. Метою розвідки $є$ відображення мовленнєвої реалізації психологічного аспекту емоційності за допомогою лінгвістичних категорій емотивності й оцінності. Поставленою в дослідженні метою передбачено виконання таких завдань, як визначення ролі емотивного й оцінного компоненту у структурі лексичного значення слова й аналіз особливостей функціонування англійських емотивних прикметників.

Сутність категорій емотивності й оцінності, а також засоби їх вираження стали предметом вивчення таких вітчизняних та зарубіжних мовознавців, як Н. Арутюнова, О. Бєссонова, Н. Бойко, Т. Вендіна, О. Вольф, Н. Лук'янова, Т. Маркелова, В. Телія, В. Чабаненко та інших.

При з'ясуванні сутності емоцій у мовознавчій науці доводиться зіштовхуватися 3 великою кількістю різноманітних підходів до їх визначення, які подаються лінгвістами в їх розвідках. Так, наприклад, В. І. Шаховський стверджує, що «емоції - це одна з форм відображення світу, відношення, у яких вони знаходяться до людини, тобто це не властивості предметів і явищ, а їх значення для життя людини. Емоції $€$ способом оцінки цього значення для конкретної людини і через неї інформацією про стан внутрішнього «я», іï свідомості та психіки.

() Н. О. Мельничук, 2014.

$-100-$ 
Емоції є тільки там, де $є$ інтерес...» [8, с. 24-25]. У свою чергу, В. І. Жельвіс вважає, що емоції - це такий спосіб ставлення людини до навколишнього світу та до самої себе, який виражається у вигляді безпосереднього переживання [5, с. 8].

Основним принципом зарахування слова до рядів емотивної лексики, на думку більшості лінгвістів, $€$ зовнішня функціональна ознака: якщо слово виражає чи здатне виражати емоції, то воно $\epsilon$ емотивним. Отже, емотивна лексика значно відрізняється від номінативної, адже ії семантичним призначенням $є$ не тільки номінація денотата, але й вираження емоційного ставлення мовця до ситуації спілкування чи до предмету мовлення. Лексика, що називає емоції, має асоціативно-емотивний характер, тому що вона, не виражаючи емоції, асоціативно відправляє свідомість мовця до сфери емоцій [8, с. 93]. Вона є лише логічною думкою мовця про почуття, тоді як лексика, що виражає емоції, $є$ безпосередньою їх маніфестацією в мовленні та супроводжується внутрішнім і зовнішнім переживанням мовця. Саме цей тип мовних засобів має емотивний характер, їх основною та невід'ємною характеристикою є емотивність.

У лінгвістичній науці емотивність визначається як «іманентно властива мові семантична властивість виражати системою своїх засобів емоційність як факт психіки, відображені в семантиці мовних одиниць соціальні й індивідуальні емоції» [8, с. 24]. В. І. Жельвіс називає емотивність вираженням емоцій, при якому спілкування зберігає свою життєвість, природність, емоційність [5, с. 4]. М. С. Ретунська стверджує, що емотивність $\epsilon$ мовним відображенням емоцій засобами різних мовних рівнів, зокрема й лексичного, який не тільки пов'язаний із вираженням емоційно-оцінного ставлення відправника мовлення, але спрямований на створення у слухача емоційного резонансу [6, с. 10].

В. І. Шаховський, досліджуючи явище мовної емотивності, з'ясував, що вона має два плани: план змісту і план вираження, через які маніфестуються емоційні ставлення / стани мовців. Крім того, у процесі дослідження автор установив три типи емотивності слова: власне емотивність, емотивність як одна 3 реалізацій семантики слова та контекстуальна емотивність. Відповідно, було виокремлено три рівні вираження емотивності: 1) емотивне значення; 2) конотація як компонент, сполучений 3 логіко-предметним компонентом значення слова; 3) рівень емотивного потенціалу. Основою першого рівня $\epsilon$ 
емотивне значення як основний ядерний компонент семантики слова, на другому рівні емотивність виражається через конотацію, яка не завжди може бути реалізована в різноманітних уживаннях слова як його компонент, тоді як рівень емотивного потенціалу нічого не змінює в семантиці слова, проте проявляє його приховану конотацію при реалізації в тексті, тобто співвіднести з мовною системою ми можемо тільки перший рівень вираження емотивності слова, у той час як два останніх залежать безпосередньо від контексту їх функціонування, a тому є периферією мовленнєвої складової.

Визначаючи емотивність як семантичну категорію, багато дослідників зосереджують увагу на іiі номінативному аспекті, інші ж, навпаки, важливішим вважають функціональний, розглядаючи мовні та мовленнєві засоби ії вираження. Емотивність лексичних одиниць відіграє неабияку роль, адже завдяки їй посилюється їх комунікативна значущість, збагачуючи, насичуючи та підсилюючи комунікативну компетенцію мовця задля прагматичного впливу на адресата: And human nature, Dr. Watson - the black ingratitude of it all! When did I ever refuse one of her requests? Was ever a woman so pampered? And that young man - he might have been my own son... And yet see how they have treated me! Oh, Dr. Watson, it is a dreadful, dreadful world! (9, c. 109).

Отже, категорія емотивності $є$ цінною складовою мовної системи іє центральною в проблемі розуміння мовної особистості, адже будь-яка людська діяльність грунтується на емоційних переживаннях, які привносять у лексику мови «ледь вловиму хімічну субстанцію» $[1$, с. 18], яка змінює їх знання залежно від комунікативних ситуацій і партнерів. Крім того, категорія емотивності є невід'ємною при вивченні контекстів різних культур, адже існування типових емоційно значущих ситуацій людського спілкування як внутрішньокультурного, так i міжкультурного зумовлює можливість виявлення спільних емоційних тем, таких як небезпека, любов, повага, смерть, тощо [2, с. 9]. Як стверджує В. І. Шаховський, «емотивність $є$ важливим компонентом прагматики мови, тому що найяскравіше втілює іiі впливову функцію: словесні та несловесні емоційні реакції найчутливіші до емоційних стимулів в ролі яких можуть виступати і емотиви - спеціальні засоби всіх поверхів мови» [8, с. 5].

Співвідношення емотивності 3 такими близькими до неї категоріями, як експресивність та оцінність у сучасній мовознавчій парадигмі набуло неабиякого значення останнім часом, адже до цих 
пір спорідненість та відмінність їх функцій у мові та мовленні залишається нерозв'язаною до кінця проблемою.

Більшістю дослідників визнається також тісний взаємозв'язок емотивності 3 оцінністю та іiі основною категорією - оцінкою, яка протягом тривалого часу була та залишається об'єктом вивчення багатьох наук, як-от: логіка, філософія, психологія та, звичайно, лінгвістика. Природа мовної й мовленнєвої оцінності, закономірності іiі прояву та різновиди і досі залишаються дискусійними в мовознавстві. Передусім це стосується сплутування понять «оцінності» й «оцінки», сутність яких істотно відрізняється, адже оцінність - це суто мовна категорія, у той час як оцінка може розглядатися серед категорій логіки. У зв'язку з цим розмежування мовної оцінності й екстралінгвістичної оцінки є принциповим. Оцінка належить до сфери свідомості людини і формується як результат засвоєння й усвідомлення цінностей, які володіють неабиякою аксіологічною значущістю, перетворюючи саму оцінку на аксіологічну категорію, нерозривно пов'язану 3 номінативною та комунікативною функціями мови, а тому оцінка $\epsilon$ антропоцентричною й універсальною категорією, що формує національну специфіку сприйняття світу, має досить складну структуру.

Найважливішою особливістю будь-якої оцінки $\epsilon$ обов'язкова присутність у ній суб'єктивного фактора, що завжди взаємодіє 3 об'єктивним: «Оцінка міститься всюди, де відбувається зіткнення суб'єкта пізнання з об'єктивним світом» [6, с. 142]. Суб'єктом оцінки вважається особа (група осіб), яка приписує цінність певному предмету шляхом вираження відповідної оцінки. Отже, завдяки цьому критерію суб'єкт хвалить, осуджує чи висловлює байдужість до певних речей, а саме це дає змогу розподілити емоційну лексику між двома асиметричними пластами - емосемізмами 3 позитивною чи негативною оцінкою в їх семантиці: The jarring note was sounded by $\mathrm{Mr}$ Gooch. He ate too noisily, drank far too freely, got on Proudfoot's nerves and behaved to Mr Spiller with a kind of veiled insolence which was embarrassing and disagreeable to listen to; His pressure lingered - he would have kissed the hand, so insidious was the scent of the red and white hawthorns in her trim garden...; The new generation, he thought sadly, did not make love like the old. He hoped there was nothing wrong. Another irritating thought presented itself $(9$, c. 71-74).

Необхідно підкреслити, що така диференціація $є$ умовною, адже тільки виявлення домінувального компонента у складному 
психологічному стані людини дає змогу зарахувати його до групи позитивних чи негативних емоцій. Відповідно, такий критерій має суто мовний характер, адже оцінка, наявна у значенні емотиву, не є власне оцінкою. При цьому необхідно враховувати, що одна і та ж лексема здатна виражати і протилежні емоції в межах певного контексту залежно від індивідуального, але в межах соціального досвіду мовця. Це явище лінгвісти називають оцінною амбівалентністю.

Оцінність як мовна категорія $є$ їі фундаментальною властивістю, яка безпосередньо пов'язана 3 пізнавальною діяльністю людини: «Наша думка постійно та навмисно додає до найменшого сприйняття елемент оцінки» [8, с. 194]. У лінгвістиці оцінність слід розуміти як закладену в слові позитивну чи негативну характеристику людини, предмета чи явища. Вона буває імпліцитною (міститься в одній із сем слова) та експліцитною (властива не конкретному слову, а його дискурсивному вживанню).

Результатом реалізації категорії оцінності в мовленні $\epsilon$ оцінне значення, яке визначається деякими лінгвістами як «інформація, що містить відомості про ціннісне ставлення суб'єкта мовлення до певної властивості, виокремленої відносно того чи того аспекту певного об'єкта» [7]. Оцінне значення в мові протиставляється дескриптивному як такому, що лише описує й інформує.

Особливий інтерес дослідників та лінгвістів до проблем оцінної семантики й емотивної лексики зумовлений насамперед тим, що оцінне значення втілено в конкретні мовні структури - наявні цілі шари лексики, призначені для вираження оцінки. Сюди належать і ад’єктивні одиниці, адже саме прикметнику, через велику концентрацію в ньому оцінності, приділяється основна увага в мовній парадигмі маніпулятивних засобів. У семантичному плані прикметники визначаються як слова, що виражають значення якості, властивості чи ознаки предмета. Їх мета - описувати, характеризувати предмети та явища 3 позиції їх статистичних (на відміну від динамічних, що виражаються дієсловами) ознак. Зазначимо, що прикметник володіє складною семантичною структурою та характеризується наявністю денотативних i конотативних компонентів, які утворюють його внутрішню форму. Опис ад'єктивної лексики пов'язаний з великою кількістю проблем, зумовлених особливим характером iї номінації, адже за своєю семантикою прикметники надзвичайно багатопланові.

Ад’єктиви мають одну спільну семантичну характеристику, яка () Н. О. Мельничук, 2014. 


\section{СТРУКТУРА I СЕМАНТИКА МОВНИХ ОДИНИЦЬ}

дає змогу об'єднати їх в єдиний клас, а саме: сигніфікативний характер їх семантики. Крім того, прикметники як класичні предикати позначають власне ознаку й оцінку, які реалізуються в межах одного висловлювання та об’єднують у своїй структурі семантичний і прагматичний аспекти мови. Важливим є й те, що ад’єктиви у своїй абсолютній формі завжди допускають наявність оцінної шкали, що уможливлює утворення тематичних груп ад'єктивних слів за їх оцінним значенням та позитивною чи негативною характеристикою. За своєю семантикою прикметники складають безперервний ряд: від власне оцінних («хороший / поганий») до позбавлених оцінного значення (відносні) прикметників.

Наше дослідження виконано на матеріалі провідного тлумачного словника англійської мови [10], з якого методом суцільної вибірки було вибрано ад’єктивні одиниці, що характеризуються різноманітністю оцінної семантики, серед них виділяється група слів загальної оцінки, що їх значення зводиться до вираження оцінки без вказування на будь-які ознаки, а також групами емотивних прикметників негативної та позитивної оцінки, що виявляють несхвальне або схвальне ставлення носіїв мови до предметів, фактів i явищ об’єктивної дійсності. Меліоративні лексичні одиниці виражають схвалення, похвалу, любов, захоплення, повагу, співчуття, пестливість, доброзичливість, прихильність, ввічливість та інші позитивні відтінки значень, наприклад: amazing - very good, especially in an unexpected way, so surprising you can hardly believe it; cheery happy or making you feel happy; chivalrous - a man who is chivalrous behaves in a polite, kind, generous, and honourable way, especially towards women; compassionate - feeling sympathy for people who are suffering; discreet - careful about what you say or do, so that you do not offend, upset, or embarrass people or tell secrets; effusive - showing your good feelings in a very excited way; spirited - having energy and determination; straightforward - honest about your feelings or opinions and not hiding anything; sympathetic - caring and feeling sorry about someone's problems; vivacious - someone, especially a woman, who is vivacious has a lot of energy and a happy attractive manner.

Поряд із позитивними емоціями, емотивні прикметники мають властивість відтворювати широку палітру негативних відтінків у своїх значеннях, як-от: зневага, приниження, нехтування, відраза тощо. Негативна оцінка вказує на те, що об’єкт характеризується небажаними 
властивостями, ознаками або мовець висловлює негативне ставлення до предмета мовлення: haughty - behaving in a proud unfriendly way; mad angry, crazy or very silly; maudlin - talking or behaving in a sad, silly, and emotional way, especially when drunk; overweening - too proud and confident; pathetic - something or someone that is pathetic is so useless, unsuccessful, or weak that they annoy you; querulous - someone who is querulous complains about things in an annoying way; saccharine - too romantic in a way that seems silly and insincere; shameful - shameful behaviour or actions are so bad that someone should feel ashamed; shitty bad, unpleasant, or nasty; virulent - full of hatred for something, or expressing this in a strong way.

Як свідчать приклади, у самій семантиці прикметників виявляються пов'язаними власне семантичний і прагматичний плани висловлювання. Якщо в інших частинах мови ці аспекти, зазвичай, не поєднані, а їх безпосередній зв'язок реалізується тільки у висловленні, то в ад'єктивних одиницях взаємодія відповідних аспектів відображається в їх значеннях. Свою функцію прикметники реалізують через поєднання 3 іменниками, адже, уточнюючи поняття, названі іменниками, вони увиразнюють та конкретизують висловлення.

Розглядаючи зв'язок категорій емотивності й оцінності, необхідно зазначити, що в роботах деяких науковців емотивність розглядається як факультативна частина оцінності. Як зазначає О. М. Вольф, емотивність $€$ в усіх оцінних висловленнях, відображає присутність у них суб'єкта [3]. Автор вважає, що емотивність інтегрована 3 оцінністю, складається 3 оцінного мовного змісту та експресивного вираження; крім того, причина емоції є об'єктом оцінки з боку суб'єкта емоції: «у складній взаємодії суб'єкта оцінки та її об'єкта можна виділити компонент, який припускає ставлення (хороше/погане) суб'єкта до об'єкта. Цей компонент можна назвати «оцінністю» або «емотивністю» [3, с. 37-39], тобто емотивність завжди одночасно виражає й оцінність, а засоби актуалізації категорії емотивності є одночасно і способами вираження оцінки.

B. I. Шаховський [8] підкреслює, що емотивність завжди припускає присутність оцінності, проте раціональна оцінність не завжди пов'язана 3 емотивністю. Дослідник розглядає ці поняття як два самостійних компоненти значення, надаючи головну роль емотивності в їх інтеграції: емотивний компонент завжди є оцінним, але якщо слово оцінне, воно необов'язково при цьому повинно бути емотивним. Відповідно, оцінність $\epsilon$ обов'язковим елементом емотивності, а одне і те ж слово в різних () Н. О. Мельничук, 2014. 
мовленнєвих ситуаціях може виражати або тільки емоцію, або одночасно і емоцію, і оцінку.

Отже, оцінку виділяють як окрему фазу породження емоцій, оскільки озвучення емотивних реакцій мовця великою мірою залежить від різних видів оцінки, як-от: моральна, побутова, етична, раціональна, логічна, емоційна, естетична, сенсорна, а тому можна припустити, що поняття оцінки є ядерним компонентом емотивності, адже будь-яка емоція в реальності містить у собі оцінку.

Термінологічна різноманітність у системі відображення емоцій у мові та мовленні зумовлює різноманітні підходи до вивчення власне поняття емотивності та невід'ємної від неї категорії оцінності, дослідження яких залишається актуальним завданням емотиології. Проведене дослідження робить певний внесок у розробку загальної теорії аналізу прикметників у мовознавстві та теорії лексичної семантики. Перспективи подальших досліджень розглядуваного питання полягають у вивченні лінгвостилістичних особливостей англійських ад'єктивних емосемізмів та глибинному аналізі їх семантичної структури.

\section{Література}

1. Барт Р. Основы семиотики / Р. Барт // Французская семиотика. От структурализма к постструктурализму. - М. : Прогресс, 2000. -208 с.

2. Волкова Н. Н. Распространение компонентного состава фразеологизмов, обозначающих эмоции / Н. Н. Волкова // Начало пути : сборник научных работ молодых учёных и аспирантов филологического факультета ВГУ - Вып. 2. Языкознание. - Воронеж, 2004. - 173 с.

3. Вольф Е. М. Функциональная семантика оценки / Е. М. Вольф. - М. : Едиториал УРСC, 2002. $-260 \mathrm{c}$.

4. Дяков А. С. Основи терміноведення : семантичні та соціолінгвістичні аспекти / А. С. Дяков, Т. Р. Кияк, З. Б. Куделько. - К. : Вид. дім «КМ Academia», 2000. - 218 с.

5. Жельвис В. И. Эмотивный аспект речи: психолингвистическая интерпретация речевого воздействия / В. И. Жельвис. - Ярославль : ЯрГУ, 1990. - 81 с.

6. Колшанский Г. В. Соотношение субъективных и объективных факторов в языке / Г. В. Колшанский. - M. : URSS : КомКнига, 2005. - 232 с.

7. Телия, В. Н. Коннотативный аспект семантики номинативных единиц [Текст] / В. Н. Телия. - М. : Наука, 1986. - 143 с.

8. Шаховский, В. И. Категоризация эмоций в лексико-семантической системе языка [Текст] / В. И. Шаховский. - М. : ЛКИ, 2008. - 208 с.

9. Crime never pays. Short stories / Edited by Clare West. - Oxford: OUP, 2000. - 144 p.

10.Longman Dictionary of Contemporary English. - Harlow : Longman, Pearson Education, 2009. - 2082 p.

Стаття надійшла до редакиії 19.10.2014 p. 